\title{
COMBATING CORRUPTION IN NIGERIA: THE ROLE OF FORENSIC ACCOUNTING
}

\author{
Lodikero Olusola and Olateru-Olagbegi Adeparubi \\ Department of Accountancy \\ Rufus Giwa Polytechnic, Owo \\ http://dx.doi.org/10.38193/IJRCMS.2021.3405
}

\begin{abstract}
This study aims at exploring the role of forensic accounting in curbing corruption in Ondo State Public Sector. Corruption is a problem of global concern. It is a major concern to developing nations of the world. There have been several cases of abuse of political power bordering on corruption charges levied against political office holders, companies and individuals operating in both the private and public sector of Nigeria economy. Therefore, this study seeks to explore the role a forensic accountant can play in the fight against financial crimes by applying his investigative skills, providing litigation support service, documentation and reporting. The data collection was done randomly through the use of questionnaires to audit and accounts unit in some Ministries, Department and Agencies (MDA's) in Ondo State, Nigeria with 220 sample size. Data collected were analyzed using a regression model. Results from the data analysis reveal that Forensic accounting has a significant impact in fighting financial crimes in Ondo state MDAs and recommend that forensic accountant should be employed by this MDAs in order to reduce incidence of economic crimes and corruption so as to enhance economic growth and development.
\end{abstract}

KEYWORDS: Crime, Corruption, Forensic Accounting, Developing Nations, Financial crimes

\section{INTRODUCTION}

Nigeria, a country richly endowed with monumental geographical and diverse natural resources became an independent nation on the 1st October 1960. In spite of these obvious resources and its advantage to the country, Nigeria remains a poor and a developing nation. Scholars have achieved and advanced several reasons to explain this parlous and depleting state. One of the major and prominent factors advanced is financial crime.

The negative roles of corruption in nation building cannot be over-emphasized. It has resulted to reduction in the growth and infrastructure of many nations and led many firms to the road of bankruptcy (Johnson-Rokosu, 2013). Kasum (2010), states that the rapid increase in financial irregularity globally is generating a lot of concerns, majorly to developing nations, an endemic that has become a normal way of life. Corruption is the largest single inhibitor of equitable economic development in many countries of the world including Nigeria, which Ondo State is a segment. 
Corrupt practices manifest itself in various ways which includes; bribery, embezzlement, fraud, favoritism, extortion, conflict of interest, political bargains, pensions, salaries and wages, in legislative process as well as other areas of government business, abuse of discretion and abuse of power (Onakuse, 2004; Habtermicheal, 2009; Dada, 2014). This act undermines good government, distortion of public policy, misappropriation of resources, harms both the public and private sector development, and particularly it hurts the poor (Dada, 2014). Many developing nations including Nigeria enact laws, set up tribunals, probe panels and established anticorruption institutions to combat the menace of fraud and corruption, but all these laws did not reduce cases of corrupt practices (Owolabi, Dada \& Olaoye 2013; Dada, 2014).

Even, conventional auditing has become ineffective in its preventive role, and lack of integrity which is an essential quality of an auditor. This means there is need to devise different means of tackling corruption taking into consideration the types of corruptions, perpetrators, the mode of perpetration, and the duties of auditors (internal and external) as enshrined in the governing statutes. In response to this, forensic accounting came to the fore. Forensic accounting is perceived to have evolved in response to certain emerging corruption related cases and the increasing sophistication of corruption requires that forensic accounting be added to the tools necessary to bring about the successful investigation and prosecution of those individuals involved in criminal activities (Nwosu, 2015). It is against this backdrop that the study seeks to examine the effect of forensic accounting in combating corruption in Nigeria.

\section{LITERATURE REVIEW}

\section{Concept of Corruption}

Corruption is a worldwide phenomenon. It is pervasive both in the rich nations and poor nations alike and especially those of the sub-Sahara Africa including Nigeria. Academic and policy discussion on corruption in Nigeria has remained an opened debate (Aluko, 2002; Ogbeidi, 2012) This is particularly common among researchers, media houses and the common man on the street (Sheu, 2015) This has no therefore created a bad image for the country among comity of Nations. For example, the annual reports of Transparency International ranked Nigeria among countries of the World with a high perceived level of corruption (Transparency International, 2012). Also, United State Department of International Affairs (2012) reported that there exist massive corruptions in Nigeria affecting every sector of the economy and doubted the efforts of the Nigerian Government in fighting economic and financial crimes, not minding the various anti-corruption agencies in the country.

According to Atelhe \& Agada (2014), corruption is a derivation of Latin origin, "corruptus" which stands for; "to destroy", and it has been variously described as a means of perversion or a procedure of changing good into bad. However, Egwemi (2012) traces the origin of the word differently. He sees the word corruption as originating from "rumpere", a Latin verb meaning "to break". Whatever may 
be the origin of the word, corruption is obviously portrayed in a negative posture as indicated by the two views. Section 2 of the Corrupt Practices and Other Related Offences Act, (2000), defines corruption to included bribery, fraud and other related offences. Olaniyan (2002) defined corruption to include bribery, fraud and dishonesty, which is capable of destroying or perverting the purity of societal well-being. Sentusia (1993) described it as misuse of entrusted power for private benefit. Also, The World Bank (2005) asserted that corruption undermines development by distorting the rule of law and weakening the institutional foundation on which economic growth depends. Obasanjo (2003) opines that at the root of the corruption quagmire in Nigeria, is the failure and virtual collapse of governance, the contamination of democratic value, the erosion of accountability procedures and the prevalence of bad leadership.

Even though some of these definitions of corruption have been around for decades, the recent development in Nigeria where discoveries of stolen public funds run into billions of US Dollars and Nigeria Naira, make these definitions very adequate and appropriate. Corruption is probably the main means to accumulate quick wealth in Nigeria. Corruption occurs in many forms, and it has contributed immensely to the poverty and misery of a large segment of the Nigerian population (Dike, 2002). The country needs a relief from ethical decadence through the application of forensic accounting education.

\section{Concept of Forensic Accounting}

Mitrić, Stanković, and Lakićević (2012) opined that the practice of forensic accounting could be traced back to 1817, where a decision of a court on bankruptcy was based on the testimony of an accountant. They further stated that a Scottish accountant used his knowledge and expertise through opinion to support arbitration proceedings in the 1820s. Several articles examined revealed expert testimonies and evidence on arbitration in the late 1800s and the early 1900s. However, "forensic accounting" was used by Kautilya who stated several means of embezzlement, but the term was coined in 1946 by Peloubet (Joshi, 2003; Crumbley, 2001).

That is, forensic accounting is not new in the world; nonetheless, many countries are unaware of this profession even though they need it badly. Though forensic accounting is dated back to the 1800s, it was noted from the review that there is no single definition for it. It is also known as investigative or fraud audit or even judicial accounting and is the unification of accounting, auditing, investigation, and law. Crumbley (2003) explained forensic accounting as the examination and interpretation of legal facts and evidence, and expert witnessing in the court of law.

Forensic Accounting is the application of investigative and analytical skills for the purpose of resolving financial issues in a manner that meets standards required by courts of law (Hopwood, Leiner, and Young, 2008). According to Curtis (2008), forensic accountants are essential to the legal 
system, providing expert services such as fake invoicing valuations, suspicious bankruptcy valuations, and analysis of financial documents in fraud schemes. It is the integration of accounting, auditing and investigative skills (Dada, Owolabi and Okwu, 2013). Onodi, Okafor and Onyali (2015) are of the opinion that forensic investigative skills are required to uncover and establish the occurrence of financial crimes due to the incidence of fraud and misappropriation of funds in recent time that is posing a threat to traditional auditing as a branch of accounting profession. It is concerned with the evidentiary nature of accounting data, and as a practical field concerned with accounting fraud and forensic auditing; compliance, due diligence and risk assessment; detection of financial misrepresentation and financial statement fraud. Crumbley (2003) defined forensic science as the application of laws of nature to the laws of man. He described forensic scientists as examiners and interpreters of evidence and facts in legal cases that also offers expert opinions regarding their findings in court of law. Dhar and Sarkar (2010) define forensic accounting as the application of accounting concepts and techniques to legal problems. It demands reporting, where accountability of the fraud is established and the report is considered as evidence in the court of law or in administrative proceedings. Forensic accounting is a discipline that has its own models and methodologies of investigative procedures that search for assurance, attestation and advisory perspective to produce legal evidence.

Forensic accounting is rapidly growing in today's accounting and it involves the detection and prevention of financial and white-collar fraud. The combination of accounting, auditing, and investigative skills combined to give birth to the specialty called Forensic Accounting, which main area of concern is to detect or prevent economic and financial crimes. The word Forensic means "Belonging to, used in or suitable to the courts of judicature or public discussion. Accounting is a system of summarizing and recording business and financial transactions which analyzes, verify, and record the results." The term 'forensic accounting' is called financial fraud investigation which includes the analysis of accounting records to prove or disprove financial fraud and to serve as an expert witness in Court to prove or disprove the same. Thus, forensic accounting aims at using accounting report in a form suitable for legal purposes (as cited in Durvesh S. Naik, 2014).

\section{Conceptual Framework}

The conceptual framework depicts a schematic relationship between proxy variables of forensic accounting and how they combine to and individually mitigate corruption. The forensic accounting proxy variables used in the context of this study include forensic accounting experience, forensic accounting awareness, forensic accounting education, forensic accounting skills, and forensic accounting with litigation support services. For instance, forensic accounting experience refers to the number of years spent in the organization. The longer an employee stay in the organization the more he gain experience and understand the rules and regulations of the establishment and know how to get away with financial crime/fraud. Forensic awareness by individuals and establishments whether in the 
public and private sector is a necessary factor to understanding how it can influence the mitigation of financial crime. Forensic accounting education is the knowledge learnt and acquired about forensic accounting, its potency when applied to detect and investigate financial crime. This is one of the reasons there is the advocacy for tertiary institution like the universities to include forensic accounting as a course and field of study. This is believed to engender training of individual and in turn contribute to the production of experts in the use of forensic accounting knowledge and skills at detecting, investigating and preventing financial crime whether in public or private sector of the economy. The end point of forensic accounting education is the acquisition of forensic accounting skills gear towards detecting, investigating and preventing financial crimes, it therefore portends that individual or establishment convicted must be litigated. In doing this, it promote efficacy of forensic accounting and its application in the general financial crime investigation and litigation in a competent court. Hence a nexus should exist between forensic accounting services with litigation and mitigation of financial crime whether in the public or private sector. Given this, forensic accounting services may be highly demanded for financial crime investigation. Based on this view, this study is a non affirmative position conjectures that forensic accounting does not significantly contributes to mitigation of fraudulent practices.

\section{Empirical Review}

Several researchers have sought to know how forensic accounting contributes towards mitigation of fraud and curbing corruption under varying scopes and with the use of divergent estimation techniques. The results they obtained are mixed. For instance, Akani and Ogbeide (2017) empirically examined the effect of forensic accounting on fraud in the Nigeria Public Sector. The study employed the survey descriptive research design. Structured four-scale likert type questionnaire was used to elicit response from the respondent. The data were analyse using frequency counts and simple percentage while the hypothesis were tested. The findings revealed that there is a significant relationship between forensic accounting and reduction of frauds in the Nigerian public sector.

Abuh and Yanusi (2018) assessed forensic accounting at combating financial crimes in Nigeria Public Sector through the effort of EFCC. Secondary data were used. A sample of 116 was obtained of the total population of 164 using Taro Yamane sample size statistical technique. Five point Likert scale questionnaire was employed while analysis of variance (ANOVA) was used to test the research hypothesis. The study findings indicate that the application of forensic accounting skills and techniques has contributed immensely in the investigation of complex financial crimes thereby enhancing economic stability.

Ocansey (2017) examined forensic accounting and the combating of economic and financial crimes in Ghana. The study employed survey research design by sampling all the technical officers (66) of Economic and organized crime office of Ghana and data were analysed through regression method. 
The study found that the application of forensic accounting technique has significant impact on combating of economic and financial crimes.

Amake and Ikhatua (2016) examined forensic accounting and fraud detection in Nigeria public sector. A research survey design was used for the study while a sample of One hundred (100) respondents comprising of auditors and accountants of four (4) ministries was selected from Edo State in Nigeria. Analysis of Variance (ANOVA) was used to test the hypothesis. The finding revealed that the application of forensic accounting in Nigeria's public sector is effective in detecting fraud; and there is s significant relationship between forensic accounting and litigation service in Nigeria court.

Ogiriki \& Appah (2018) empirically analysed the effect of forensic accounting and auditing techniques on public sector fraud detection, investigation and prevention in Nigeria. Specifically, the study sought to establish the effect of the various techniques of forensic accounting on public sector fraud and secondly, to determine the effect of forensic auditing on fraud detection, investigation and prevention. The study adopted an ex-post factor design, structured questionnaire were distributed for data collection and the hypothesis were analysed using regression analysis. The study revealed that the relationship between forensic accounting and auditing techniques and public sector fraud detection, investigation and prevention in Nigeria is quite significant. The study therefore concludes that forensic accounting and auditing techniques is a major panacea to the level of fraudulent activities experienced in the Nigerian public sector. It was recommended among others that government should consider providing more fraud hotlines, improve the whistle blowing policy and establish forensic accounting department in the public sector in order to enhance the fraud detection, investigation and prevention mechanism in the public sector.

\section{METHODOLOGY}

The study is a survey research which is carried out using primary data collected through the use of questionnaire. The sample size was drawn from a population of 220 Professional accountants, auditors and managers in Ondo State Private and Public Sectors. The sample size was calculated using a statistical sampling tool known as Slovin's formula. Simple random sampling technique was use to select the MDA's and organization used for this study given the fact that it gives each individual in the given population equal chance of being selected. Eleven questionnaires were administered to 10 organizations and 10 MDA's respectively in Ondo State, Nigeria making a total of 220. Out of the 220 administered questionnaires 200 were fully completed and returned while the remaining 10 are the one that are either not fully completed or not returned. The data were analysed using Regression Statistical Technique. The model formulated for this study is as follows: 
Functional form

$\mathrm{FPr}=\mathrm{f}($ Awf, Edfr, LSs, Expf). 1

Corruption= Fraudulent Practice

Where;

Dependent Variable: Corruption; (FPr= Fraudulent Practices) Skill on Fraud

Independent Variables: Forensic Accounting; (Awf =Awareness about Forensic Accounting, Edfr= Education about Fraudulent Practices, LSs=Litigation Support Service, Expf= Expenditure on Fraud). Econometrics Form

$\operatorname{FPr}=\beta_{0}+\beta_{1} \mathrm{Awf}+\beta_{2} \mathrm{Edfr}+\beta_{3} \mathrm{LSs}+\beta_{4} \mathrm{Expf}$

\section{Data and Analysis and Discussion}

Table 1: Descriptive Statistics

\begin{tabular}{|l|l|r|r|}
\hline \multicolumn{2}{|c|}{} & Gender & Qualification \\
\hline \multirow{2}{*}{ Mean } & Valid & 200 & 200 \\
\cline { 2 - 4 } & Missing & 0 & 0 \\
\hline Median & 1.39 & 1.92 \\
\hline Variance & 1.00 & 2.00 \\
\hline Range & .238 & .446 \\
\hline Minimum & 1 & 2 \\
\hline Maximum & 1 & 1 \\
\hline Sum & 2 & 3 \\
\hline
\end{tabular}

Source: Field Survey 2020.

The descriptive statistics is the normality test for the distribution of Bio-data of the respondents based on the Organisation and Ministries, Departments and Agencies (MDAs) in Ondo state, this has shown the dispersion and central tendency in the variables from mean, median, variance, range, minimum and maximum. Gender of the Professional accountants, Auditors and Managers as a mean of 1.39 while their Educational Qualification as a mean of 1.92 with the sum of 277 and 384 respectively.

Table 2: Gender of the Respondents

\begin{tabular}{|l|l|r|r|r|r|}
\hline \multicolumn{2}{|c|}{} & Frequency & Percent & Valid Percent & Cumulative Percent \\
\hline \multirow{3}{*}{ Valid } & Male & 123 & 61.5 & 61.5 & 61.5 \\
\cline { 2 - 6 } & Female & 77 & 38.5 & 38.5 & 100.0 \\
\cline { 2 - 6 } & Total & $\mathbf{2 0 0}$ & $\mathbf{1 0 0 . 0}$ & $\mathbf{1 0 0 . 0}$ & \\
\hline
\end{tabular}


Source: Field Survey 2020.

The table above, showed the gender of staff in Organisations and Ministries, Departments and Agencies (MDAs) in Ondo state that respond to the questionnaire assigned on them about roles of forensic accounting can play in combating corruption in Ondo state, out of 200 respondents, 123 respondents were male which was $61.5 \%$, while 77 respondents were female with $38.5 \%$. This shown that more male Professional Accountants, Auditors and Managers in Ondo State believed that combatting corruption at fraudulent level in Ondo state can be releasable both at public and private sector. Below is the pie chart structure of their gender.

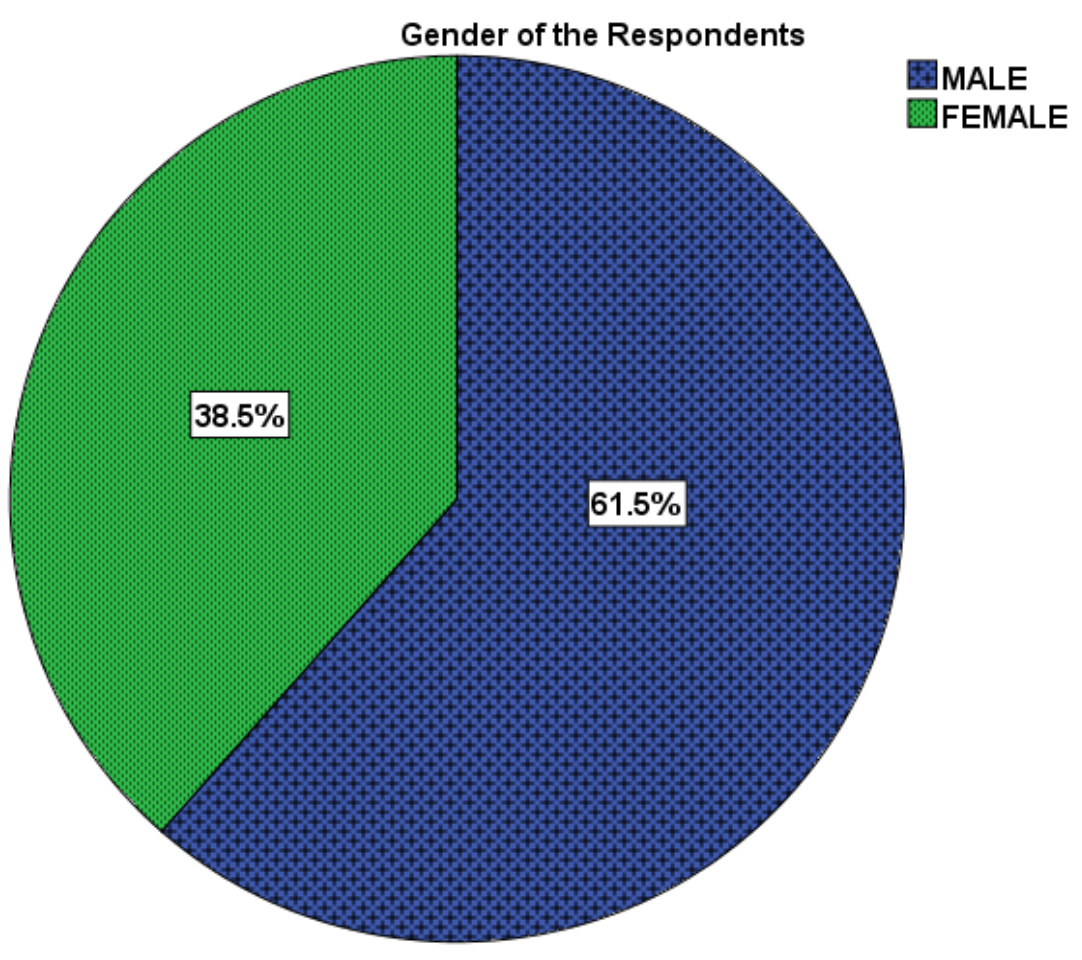

Table 3: Qualification of the Respondents

\begin{tabular}{|c|l|r|r|r|r|}
\hline \multicolumn{2}{|c|}{} & Frequency & Percent & Valid Percent & Cumulative Percent \\
\hline \multirow{4}{*}{ Valid } & HND/BSC & 53 & 26.5 & 26.5 & 26.5 \\
\cline { 2 - 6 } & MBA/MSC & 110 & 55.0 & 55.0 & 81.5 \\
\cline { 2 - 6 } & PHD & 37 & 18.5 & 18.5 & 100.0 \\
\cline { 2 - 6 } & Total & $\mathbf{2 0 0}$ & $\mathbf{1 0 0 . 0}$ & $\mathbf{1 0 0 . 0}$ & \\
\hline
\end{tabular}

Source: Field Survey 2020. 
The table three above showed Academic qualification of the staff in Organisations and Ministries, Departments and Agencies (MDAs) in Ondo state that were covered in this research, 53 of the respondent as first degree as educational knowledge like Higher National Diploma Holders and Degree Holders as well as Master and Professional qualification with 55\% and Doctorate (PhD) of 37 with $18.5 \%$. According to the analysis, it is showed therefore that more roles of forensic accounting can play in combating corruption in Ondo state. Below is the pie chart structure of their educational level.

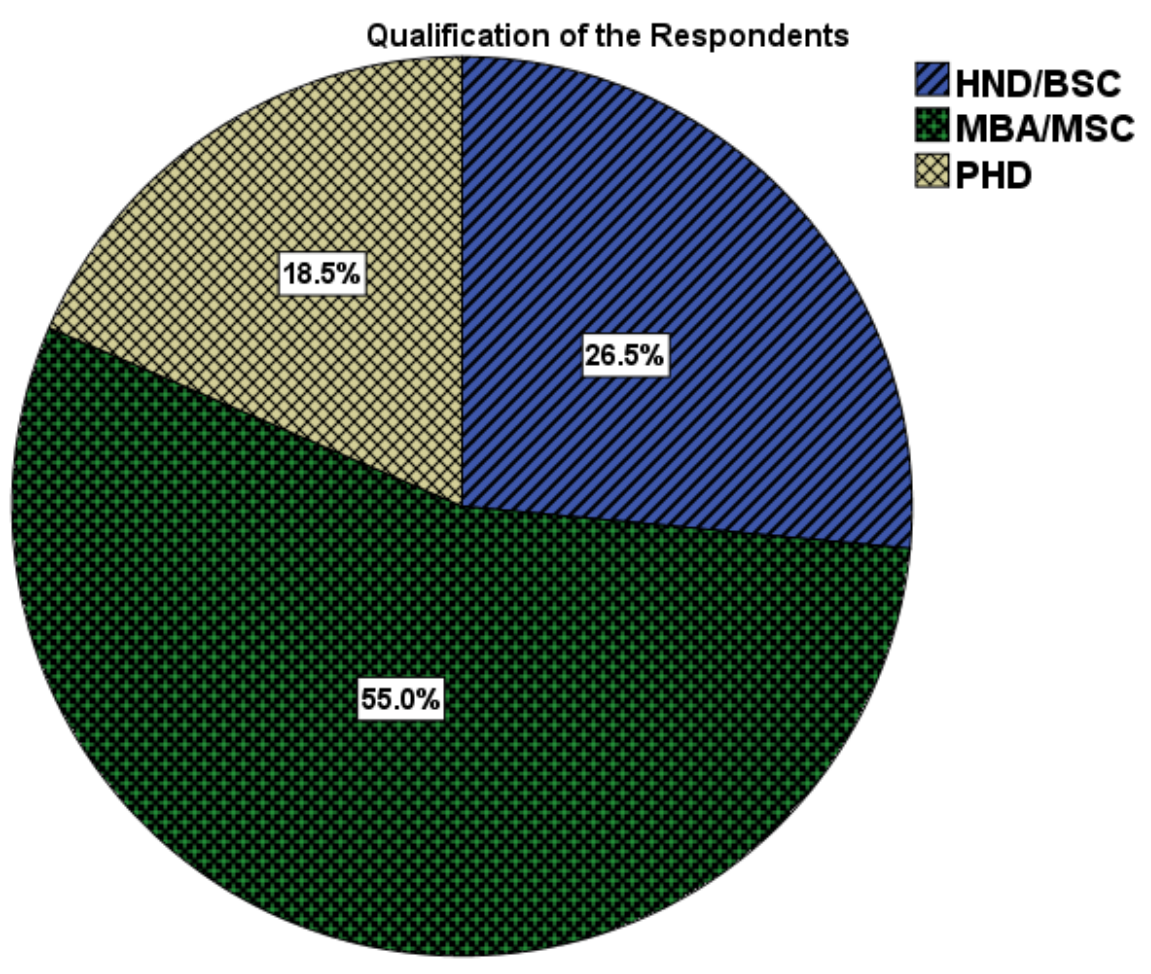

Table 4: Ordinary Least Square (OLS)

\begin{tabular}{|c|c|c|c|c|}
\hline \multicolumn{5}{|c|}{$\begin{array}{l}\text { Dependent Variable: Fraudulent Pra } \\
\text { Method: Ordinary Least Square } \\
\text { Included observations: } 200\end{array}$} \\
\hline Variable & Coefficient & Standard Err & T-statistic & Probabilities \\
\hline Constant & 1.812 & 0.335 & 5.413 & 0.000 \\
\hline Awf & 0.172 & 0.054 & 2.541 & 0.012 \\
\hline Edfr & 0.171 & 0.069 & 2.324 & 0.021 \\
\hline LSs & 0.268 & 0.063 & 3.824 & 0.000 \\
\hline Expf & 0.045 & 0.059 & 0.662 & 0.509 \\
\hline
\end{tabular}




\section{A-priori Criteria}

Source: Field Survey 2020

The test is aimed at shaping whether the signs and sizes of the results are in line with what economic theory hypothesizes. Thus, economic theory tells us that the coefficients are positively related to the dependent variable, if an increase in any of the explanatory variables leads to an increase in the dependent variable. Therefore, the variable under consideration and their parameter showing of Apriori signs have been summarized in the table below. This table will be guarded by these criteria.

When $\boldsymbol{\beta}>0$, Positive relationship.

When $\boldsymbol{\beta}<0$, Negative relationship.

Table 5: A-priori Expectation Table

\begin{tabular}{|l|l|l|l|}
\hline Variable(s) & Expected Sign & Estimate & Remarks \\
\hline Awf & $(+)$ & $B_{1}>0$ & Conform \\
\hline Edfr & $(+)$ & $\beta_{2}>0$ & Conform \\
\hline LSs & $(+)$ & $\beta_{3}>0$ & Conform \\
\hline Expf & $(+)$ & $\beta_{3}>0$ & Conform \\
\hline
\end{tabular}

Source: Author's Computation

FPr $=1.812+0.172 \mathrm{Awf}+0.171 \mathrm{Edfr}+0.268 \mathrm{LSs}+0.045 \mathrm{Expf}+\mathrm{Ut}$

$\begin{array}{llllll}\text { S.e } & (\mathbf{0 . 3 3 5}) & (\mathbf{0 . 0 5 4}) & (\mathbf{0 . 0 6 9 )} & (\mathbf{0 . 0 6 3 )} & \mathbf{( 0 . 0 5 9 )} \\ \text { T-Stat } & \{\mathbf{5 . 4 1 3}\} & \{2.541\} & \{2.324\} & \{3.824\} & \{0.662\}\end{array}$

Table 6: ANOVA Result

\begin{tabular}{|l|r|r|r|c|c|}
\hline Model & Sum of Squares & \multicolumn{1}{|c|}{ Df } & Mean Square & F & Sig. \\
\hline Regression & 35.842 & 4 & 8.960 & 14.201 & .000 \\
\hline Residual & 123.038 & 195 & .631 & & \\
\hline Total & 158.880 & 199 & & & \\
\hline
\end{tabular}

Source: Field Survey 2020 


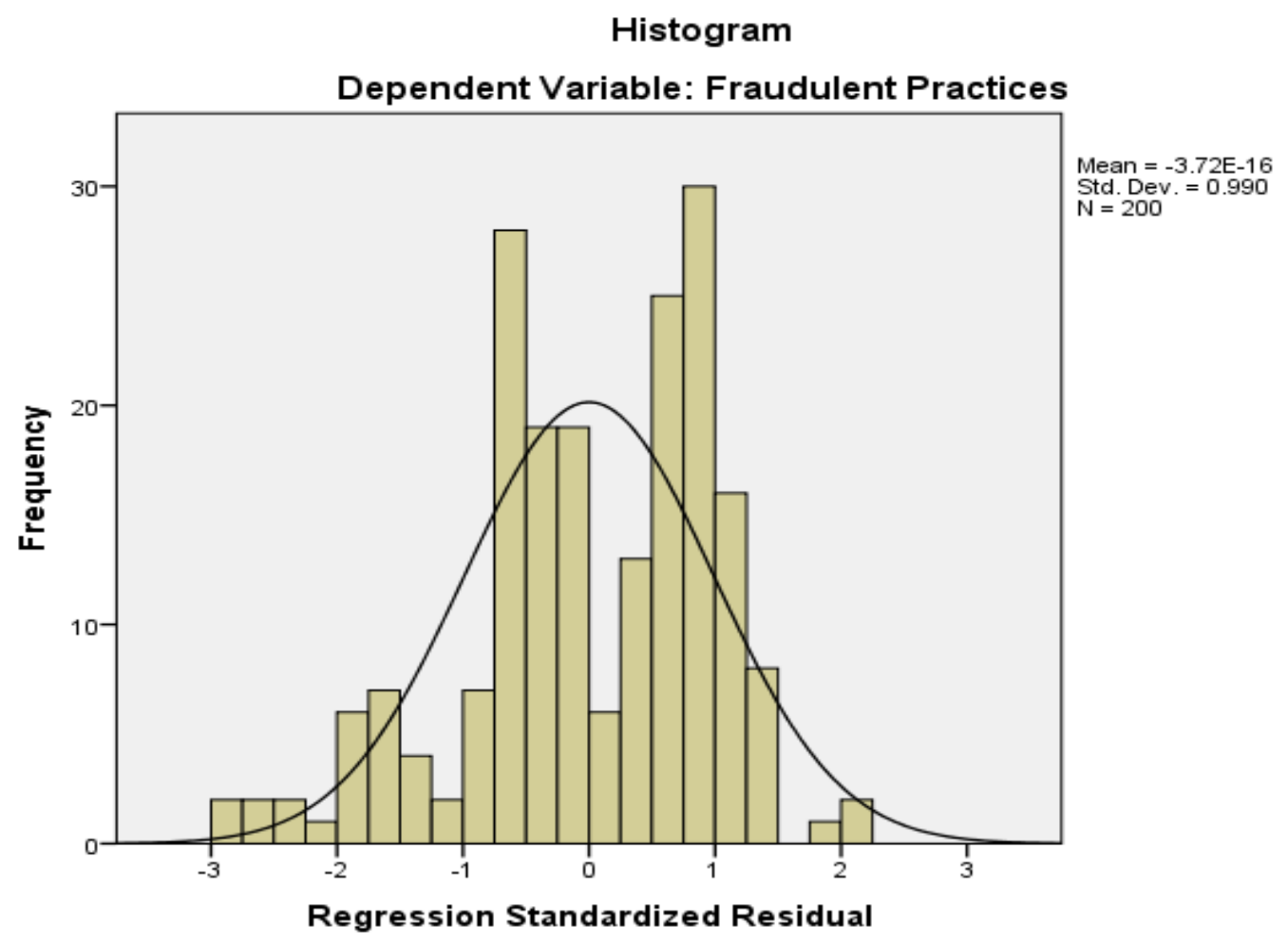

\section{DISCUSSION}

The intercept value shown was 1.812 which means, fraudulent practices (FPr) has 1.812 units when other variables are held constant, this means, the fraudulent practices has positive value when others variables were held constant and can stand alone without independents variables which serve as prevalent thing without independent variables. Awareness about fraudulent practices (Awf) shows that 1 unit increases in skill on fraud practices brought 0.172 unit increases in fraudulent practices through corruption perpetrated and it was substantial enough to justifies the fraudulent practices at all Organisation and MDAs in Ondo state but this can be curbed through forensic accounting practice in an effective way because $t$-critical value is less than $\mathrm{t}$-calculated $1.9722<2.541$, thus, it can be used for policy making by way curbing unethical behaviours at both public and private sector. Education about Fraudulent Practices (Edfr) shows that 1unit increases in Education about Fraudulent Practices brought 0.171 units increase in fraudulent practice (FPr) and it is statistically significant using rule of thumb and T-test statistic $(1.9722<2.324)$ respectively. Thus, having knowledge about fraudulent practice will corruption level but as allows by individual that commit fraud in an Organisational but forensic accounting system is a way out to curtain such attitude in an Organisation and public sector.

Litigation Support Service on Fraud (LSs) shows that 1unit increases in Litigation Support Service brought 0.268 units increase in fraudulent practices (FPr) and it was statistically significant using rule 
of thumb and T-test statistic $(1.9722<3.824)$ respectively. Thus, it can be used for policy making which will justifies the point of possibility of reducing the occurrence of fraud cases using Forensic Accounting and also, some official can also use the medium to sue government and organisation in order not to use forensic accounting system to curb them.

Expenditure on Fraud (Expf) shows that 1unit increases in Expenditure on Fraud brought 0.045 units increase in fraudulent practice and corruption (FPr) in Ondo state with the forensic accounting system serving as a way out and but it was not statistically significant using rule of thumb and T-test statistic (1.9722>0.662) respectively. Thus, having the necessary traits or skills and abilities to commit fraud, respondent believed that probity is better than dishonesty in the society. Spending on fraud committing is not in line government expectation in any circle. With this expenditure on fraud is not having more potent on fraud perpetration through forensic accounting.

\section{Statistical Criteria \{first order test}

\section{Coefficient of Multiple Determinants $\left\{\mathbf{R}^{2}\right\}$}

The $\mathrm{R}^{2}$ shows the explanatory power of the model which can be seen as $0.67825(67.8 \%)$, means, $67.825 \%$ of changes in fraudulent practices (FPr) can be explained by all explanatory/exogenous variables or are due to exogenous variables changed, while the $\mathrm{R}^{2}$ adjusted is the predictive power to shows the predictive ability of the model and this can be seen as 0.6723 (67.23\%), means, $67.23 \%$ of change in fraudulent practices (FPr) can be predicted by explanatory variables in the model. Lastly, the F-statistic shows the robustness of the model for goodness of fit by comparing F-calculated to Fcritical in the table, in order to explain the impact of whole explanatory variables on dependent/explained variable, and this was shown by 0.05 level of significance which is and 2.5581 and is less than 14.201, $(2.6802<14.201)$ calculated.

\section{FINDINGS}

Base on the fact and empirical findings on Owojori and Asaolu (2009) that the failure of the statutory audit and the refined financial fraud in recent times had led to the need for forensic audit. Thus, the forensic accountant could be said to have special tools for conducting investigation as to detect and prevent fraudulent activities thereby combating financial fraud. The intercept shown was 1.812 which means, fraud detection and corruption level in private and public sector (FPr) 1.812 units when others variables are held constants, this means, fraud has fraud detection and constant and can stand without independent will bring 1.812 unit increase in fraud detection and prevention (FPr) and it was substantial enough to justifies the fraudulent practices in an Organisation like in Ondo state. Forensic accountant being a fraud investigator is very much likened to a surgeon who requires significant amount of diagnostic and explanatory work to discover what really is happening. In view of the above, it can be said that a forensic accountant goes afar the normal audit as to divulge fraudulent activities by using forensic software tools in accompanying and investigating connections and actions. 
Education about Fraudulent Practices by government officers boost their awareness about fraudulent practice in the government circle, by so doing, corruption level increases which can be only control by forensic accounting practice in the state. Litigation Support Service on Fraud also serve as a way of building confidence by government officers in the offices in Nigeria, which they can used against the government in order to perpetrate their fraudulent practices and corruption level but with the aide of forensic accounting system fraud can be detected and find tune. Expenditure on fraud (Expf) as a variable also aide fraudulent act in an organisation either in private or public sector. The role of a forensic accountant under contemporary conditions no doubt is very important because they help lawyers, courts, the police, regulatory bodies and other institutions in investigating and documenting frauds which can also occurred in Ondo state.

\section{Conclusion and Recommendations}

\section{CONCLUSION}

The study concluded that the forensic accountants/auditors play a vital role in any organisation they are working. Forensic accounting and auditing techniques is a major panacea to the level of fraudulent activities and corruption experienced in the Nigerian public and private sector. Well-functioning forensic tools could be fundamental for fraud prevention and detection which will promote forensic auditing profession in Nigeria and world at large.

\section{RECOMMENDATIONS}

In the light of above conclusion, the study recommends the following;

i. Government should develop more interest in forensic accounting for monitoring and investigating suspected culprits in fraud cases as evidenced in the examples earlier cited.

ii. Our laws should be up to date with latest advancement in technology to ensure admissibility of evidence in a law court for successful prosecution of criminal and civil cases. Government should have an effective plan with other countries in extraditing run away fraudsters from anywhere around the globe.

iii. Professional accounting bodies should conduct forensic accounting training for accountants regularly.

iv. It is also recommended that government should ameliorate the expenses involved in engaging the services of a forensic accountant.

v. Based on the prevalent cases of fraudulent acts, forensic accountant should be employed in order to reduce incidence of economic crimes and corruption so as to enhance economic growth and development, and consequently, there should be a strong drive effective compliance law that will guide the operation of the Organisations.

vi. Also, that forensic accounting professional/experts be retained by EFCC to carry out investigation and service that will assist in prosecuting corruption cases and to reach $\mathrm{s}$ 
conclusion on issues before the court.

\section{REFERENCES}

Abu, P. \& Acho, Y. (2018). Forensic accounting and economic stability in the Nigerian public sector. The role of economic and financial crime commission. International Journal of Public Administration and Management Research, 4(3), 74-83.

Akani, C. \& Ogbeide, S.O. (2017). Forensic accounting and fraud in Nigeria. International Journal of Arts and Humanities, 6(2), 171-181. Doi;http://dx.doi.org/10.43414/ijah.v6i2.13

Amake, C.C. \& Ikhatua, O.J. (2016). Forensic accounting and fraud detection in Nigeria public sector. Igbinedion University of Accounting Journal, 2(1), 148-172

Banfield, E. (1961).The moral basis of backward society, Chicago: Free Press

Crumbley, D. L. (2001). Forensic Accounting: Older than You Think. Journal of Forensic Accounting, 11(2), 181-202.

Crumbley, D. L. (2003). What is Forensic Accounting? Forensic Accounting: Older than You Think. Journal of Forensic Accounting, 11(2), 181-202. Retrieved from http://www.edwardpub.com

Curtis, G.E., (2008) Legal and regulatory environments and ethics: Essential components of fraud and forensic accounting curriculum. Issues Account.Educ., 23(4): 535-543.

Dada, S. O., (2014). Forensic Accounting Technique: A Means of Successful Eradication of Corruption through Fraud Prevention, Bribery Prevention and Embezzlement Prevention in Nigeria. Kuwait Chapter of Arabian Journal of Business and Management Review Vol 4, No.1; September. 2014 pp. $176-186$

Dada, S. Owolabi S. A and Okwu A. T. (2013) Forensic accounting a panacea to alleviation of fraudulent practices in Nigeria. International Journal of Business Management Economics Research. 4(5)787-792. Retrieved from www.ijbmer.com

Dhar, P., \& Sarkar, A. (2010). Forensic Accounting: An Accountants vision. Vidyasagar University Journal of Commerce, 15(3), 93-104.

Dike, V. (2002). Corruption in Nigeria: A new paradigm for effective control. Elliot. Washington Institute for Urban Economics.

Habtermicheal, F. S. (2009). Anti-Corruption strategies in the South African Public SectorPerspective on the contribution of complexity thinking and ICT, PhD thesis, Stellenbosch University, South Africa

Hopwood, W. S., Leiner, J. J. \&Young, G.R.(2008).Forensic Accounting. New York: McGrawHill/Irwin.

Johnson-Rokosu, S.F., (2013). An Empirical Evaluation of Fraud and Forensic Accounting Education in Nigerian Tertiary Institutions. Unpublished M.sc (Accounting) thesis, University of Lagos, Nigeria.

Joshi, M. S. (2003). Definition of Forensic Accounting. Retrieved from http://www. forensicaccounting.com

Kasum, A.S., (2010). The relevance of forensic accounting to financial crimes in private and

Mitrić, M., Stanković, A. \& Lakićević, M. (2012). Forensic Accounting - the Missing Link in Education and Practice. Management Journal for Theory and Practice Management, 65, 4150. https://doi.org/10.7595/management. From. 2012.0032. Retrieved from http://www.management.fon.rs 
ISSN 2582-2292

Vol. 3, No. 04 July-Aug; 2021

Nye, J. S. (1967). Corruption and political development: A cost-benefit analysis. Political Science Review.LXI2 June 1967 pp.417-27 Quoted in Heidenheimer, J. Arnold; Michaek

Nkom, B. (1982). Nigeria, Corruption in Development. A paper presented at the conference of the Nigeria Anthropological and Sociological Association, Zaria. Kaduna State. Ibadan University Press. Ibadan. Nigeria.

Nwosu, M.E., (2015). Forensic auditing and financial accounting in Nigeria: An assessment. International Journal of Economics and Management Studies, 2(7), 6-11

Obayelu, A.E. (2007). Effects of corruption and economic reforms on economic growth and development: lessons from Nigeria

Ocansey, E. (2017). Forensic accounting and the combating of economic and financial crimes in Ghana. European Scientific Journal, 3(31), 185-881

Ogiriki, T., \& Appah, E., (2018). Forensic accounting \& auditing techniques on public sector fraud in Nigeria. International Journal of African and Asian Studies, 2, 7-16.

Onakuse, S, (2004). A review of corruption and sustainable development in Nigeria: A paper presented at the conference on globalization and inclusion, University College, Cork, Ireland.

Onodi, B.E., Okafor, T.G. \&Onyali, C.I. (2015).The impact of forensic investigative methods on corporate fraud deterrence in banks in Nigeria.European Journal of Accounting, Auditing and Finance Vol. 3(4),69-85.

Owojori, J. and Asaolu, F. (2009). The Role of Forensic Accounting in Solving the Vexed problem of Corporate World. European Journal of Scientific Research, 29(2), pp. 183- 187.

Owolabi, S. A., Dada, S. O., and Olaoye, S. A. (2013). Application of forensic accounting technique in effective investigation and detection of embezzlement to combat corruption in Nigeria. Unique Journal of Business Management Research Vol. 1(4), pp. 065-070. Available online@http://www.uniqueresearchjournals.org/UJBMR Public sectors of third world economies: a study from Nigeria. Journal of Finance Studies, 25(3), pp. 34-45

Sen, A. (1999). Development as freedom, New York: Anchor Books

Tanzi, V (1998). Corruption around the world: causes, consequences, scope, and cures. IMF Working Paper, Vol., pp. 1-39, May. Available at SSRN: http://ssrn.com/abstract=882334

UNODC (2004). Anti-Corruption Toolkit. [On-line] Available: http://www.unodc.org/unodc/corruption_toolkit.html. Edited by Petter Langseth and Published by the United Nations Office on Drugs and Crime).

\section{APPENDIX}

Model Summaryb

\begin{tabular}{|c|c|c|c|c|c|c|c|c|c|c|}
\hline \multirow[t]{2}{*}{ Model } & \multirow[t]{2}{*}{$\mathrm{R}$} & \multirow{2}{*}{$\begin{array}{c}\mathrm{R} \\
\text { Square }\end{array}$} & \multirow{2}{*}{$\begin{array}{l}\text { Adjusted R } \\
\text { Square }\end{array}$} & \multirow{2}{*}{$\begin{array}{l}\text { Std. Error } \\
\text { of the } \\
\text { Estimate }\end{array}$} & \multicolumn{5}{|c|}{ Change Statistics } & \multirow{2}{*}{$\begin{array}{l}\text { Durbin- } \\
\text { Watson }\end{array}$} \\
\hline & & & & & $\begin{array}{l}\text { R Square } \\
\text { Change }\end{array}$ & $\begin{array}{c}\mathrm{F} \\
\text { Change }\end{array}$ & $\mathrm{df1}$ & $\mathrm{df2}$ & $\begin{array}{c}\text { Sig. F } \\
\text { Change }\end{array}$ & \\
\hline 1 & $.475^{\mathrm{a}}$ & .226 & .210 & .794 & .226 & 14.201 & 4 & 195 & .000 & 1.683 \\
\hline
\end{tabular}

a. Predictors: (Constant), Expenditure and Fraud, Skill and Fraud, Litigation Support Service, Foreign Accounting and Education

b. Dependent Variable: Fraudulent Practices 
ANOVA ${ }^{\mathrm{a}}$

\begin{tabular}{|rl|r|r|r|r|r|}
\hline \multicolumn{1}{|l|}{ Model } & Sum of Squares & Df & Mean Square & F & Sig. \\
\hline \multirow{2}{*}{1} & Regression & 35.842 & 4 & 8.960 & 14.201 & $.000^{\mathrm{b}}$ \\
& Residual & 123.038 & 195 & .631 & & \\
& Total & 158.880 & 199 & & & \\
\hline
\end{tabular}

a. Dependent Variable: Fraudulent Practices

b. Predictors: (Constant), Awareness about Forensic Accounting, Expenditure and Fraud, Litigation

Support Service, Foreign Accounting and Education

\begin{tabular}{|c|c|c|c|c|c|c|c|c|}
\hline \multicolumn{9}{|c|}{ Coefficients $^{a}$} \\
\hline \multirow{2}{*}{\multicolumn{2}{|c|}{ Model }} & \multicolumn{2}{|c|}{$\begin{array}{l}\text { Unstandardized } \\
\text { Coefficients }\end{array}$} & \multirow{2}{*}{$\begin{array}{c}\begin{array}{c}\text { Standardize } \\
\mathrm{d} \\
\text { Coefficients }\end{array} \\
\text { Beta }\end{array}$} & \multirow[t]{2}{*}{$\mathrm{t}$} & \multirow[t]{2}{*}{ Sig. } & \multicolumn{2}{|c|}{$\begin{array}{l}95.0 \% \text { Confidence } \\
\text { Interval for B }\end{array}$} \\
\hline & & $B$ & Std. Error & & & & $\begin{array}{l}\text { Lower } \\
\text { Bound }\end{array}$ & $\begin{array}{l}\text { Upper } \\
\text { Bound }\end{array}$ \\
\hline \multirow{5}{*}{1} & (Constant) & 1.812 & .335 & & 5.413 & .000 & 1.152 & 2.472 \\
\hline & \begin{tabular}{|l|} 
Awareness about \\
Forensic Accounting
\end{tabular} & .137 & .054 & .172 & 2.541 & .012 & .031 & .244 \\
\hline & $\begin{array}{l}\text { Foreign Accounting } \\
\text { and Education }\end{array}$ & .160 & .069 & .171 & 2.324 & .021 & .024 & .296 \\
\hline & \begin{tabular}{|l} 
Litigation Support \\
Service
\end{tabular} & .241 & .063 & .268 & 3.824 & .000 & .117 & .365 \\
\hline & $\begin{array}{l}\text { Expenditure and } \\
\text { Fraud } \\
\end{array}$ & .039 & .059 & .045 & .662 & .509 & -.078 & .157 \\
\hline
\end{tabular}

